\title{
THE TESTAMENTARY CHARACTER OF PERSONAL UNFUNDED LIFE INSURANCE TRUSTS*
}

\section{Elmer I. Phillips $\dagger$}

Personal unfunded life insurance trust settlements present many problems of interest not only to attorneys but to life insurance underwriters and the many persons who may select or who have selected this method of disposing of insurance proceeds. ${ }^{1}$ One of the most important of these problems is whether the various types of settlements, some of which have been developed in recent years, are testamentary dispositions of such character as to require compliance with the formal requisites of the Statute of Wills. The great importance of the problem can be appreciated only when it is observed that today life insurance policies having an aggregate face value of four billion dollars are either held in trust or have the disposition of their proceeds affected by instruments of this general character. ${ }^{2}$ As these instruments are seldom executed in a manner which will satisfy the formal requirements of the statutes governing the execution of wills, a determination that the dispositions thereunder are of such testamentary character as to require such formal execution would jeopardize the settlements which many people have established for their dependents and, in many cases, would probably result in the insurance proceeds being paid to parties other than those specifically designated by the settlor. ${ }^{3}$

* The author wishes to acknowledge his indebtedness to B. E. Farr, Esq., of New York City, for his many helpful suggestions during the preparation of this article.

$\rightarrow$ B. S., I923, Dartmouth College; LL. B., I926, Harvard University. Member of Pennsylvania and Ohio Bars.

${ }^{1}$ Personal life insurance trusts are illustrative of one method of disposing of insurance proceeds. The so-called "optional settlement" or "deferred payment" contract sponsored by insurance companies is another type. Under the latter settlements the insured enters into a supplemental agreement with the insurance company providing for payment of the proceeds to the designated beneficiary in various ways other than by one lump sum payment. Since the parties do not contemplate, and insurance companies do not in fact allocate or segregate, any portion of their assets as a trust res under a particular contract, it is difficult to contend that a trust is created. Instead, the arrangement appears to be a contract giving rise to a debt upon the death of the insured; see HorTon, POWER OF AN INSURED to CoNTrol THE Proceeds of His Polrcies (I926) 49; Bogert, Some Recent Developments in the Lave of Trusts (I929) 23 ILI. L. Rev. 749, 753; Note (I927) 36 YaIE L. J. 394; Note (1933) 46 HARv. L. REv. 8I8. Many insurance companies include in such settlements a covenant "guaranteeing" a certain yield on principal. The use of the word "guarantee" may be questioned but its use by the companies strengthens the view that only a contract obligation is involved. Under this view, the question of whether there is a testamentary disposition is no different than in the case of the ordinary life insurance policy calling for one lump sum payment to a designated beneficiary wherein the insured reserves a right to change the designation of the beneficiary. For authorities supporting the view that a trust is created, see Note (1933) 46 HaRv. L. REv. 818, 819. If this latter view is adopted, testamentary problems similar to those presented by life insurance trust settlements must be considered.

${ }^{2}$ Note (1933) 46 HARv. L. REv. 8 I8 n. I.

${ }^{3}$ In the case of a proposed settlement the problem could be avoided by executing the trust instrument with the required formalities. Federal Trust Co. v. Damron, I24 Neb. 655,247 N. W. 589 (1933) ; Phipard v. Phipard, 55 Hun 433, 8 N. Y. Supp. 728 (1890); see also Scott, Trusts and the Statute of Wills (1930) 43 HARv. L. REv. 521, 534. Or the 
The question as to the testamentary character of unfunded life insurance trust settlements arises naturally out of the nature of this method of disposing of the proceeds. Under the great majority of these settlements the settlor designates the trustee as the beneficiary of the insurance policies with the provision that the trustee will retain the proceeds for certain purposes; or the settlor may go further and, in addition to designating the trustee as beneficiary, assign the policies to the trustee. In any event, the settlor usually reserves a right to change the beneficiary under the policies or to revoke the settlement. In the modern agreements, full power with respect to both of these matters is usually reserved. In all such cases, it lies within the power of the settlor during his life to alter the disposition of the proceeds. Since the effect of most settlements of this character is to permit the enjoyment of a beneficial interest in the proceeds by designated beneficiaries only after the death of the settlor, the question is immediately presented whether these settlements are sufficiently ambulatory to be considered testamentary dispositions requiring excution in accordance with the statute governing the execution of wills in force in the state whose law governs the validity of the disposition.

The general problem has received consideration, ${ }^{4}$ and has been discussed in some detail, ${ }^{5}$ but a complete analysis of the problem coupled with an exhaustive classification and review of authorities relating thereto has not been presented. Analysis shows that there are several well known cases, frequently cited in support of certain propositions relating to trusts inter vivos generally, which in fact involve unfunded settlements, and further that there are other cases which are not well known but which are of equal interest. There is an idea prevalent among attorneys and insurance underwriters that there are few authorities dealing with insurance trusts. This review reveals that there are more decisions dealing generally with unfunded insurance trust settlements than has been recognized heretofore. Morover, in the light of this analysis and review, it is apparent that most of the so-called "unfunded insurance trusts" may be classified in several groups having distinct characteristics and that this classification lends itself to a consideration of the particular problem to which this inquiry is addressed.

instrument might be incorporated by reference in the will of the settlor in jurisdictions where incorporation by reference is possible. In the latter case, consideration should be given to the effect which such action might have in subjecting insurance proceeds, which wotild otherwise be exempt, to clains of the insured's creditors.

" Fraser, Personal Life Insurance Trusts in New York (1930) I6 CoRs. L. Q. I9, 30; Horton, The Testamentary Nature of Settlements of Life Insurance Elected by the Beneficiary (I93I) I7 CoRN. L. Q. 72, 77; Davis, The Statute of Wills and Life Insurance, Paper read before the Association of Life Insurance Counsel, December 9, I93I; Phillips, Life Insurance Trusts: A Recapitulation for the Draftsman (I933) 8I U. of PA. L. Rev. 284,289 .

-Fraser, Legal Nature of an Unfinded Transaction, 2 Prentice-Hall Trust Servtce (1933) If 7719; Note (1933) 46 HARv. L. REv. 818. 
There is a primary argument supporting the validity of unfunded settlements. An insurance contract, apart from a trust settlement, need not be executed in conformity with the requirements of the Statute of Wills, irrespective of whether or not various powers-including a power to change the beneficiary designated in the contract-be reserved. ${ }^{6}$ This view is generally supported upon the ground that ordinary life insurance policies are valid third party contracts, one of the terms being that on certain contingencies a sum certain will be paid to a designated third party. Since this is so, it is argued that if the payment is directed to be made to a third party other than the insured's executor or administrator, the funds so paid over at no time constitute part of the insured's estate. This conclusion is supported by the fact that when insurance policies are so payable, the insured, under the usual contract requiring any change in designation of beneficiary to be registered with the insurer, cannot dispose of the proceeds by will. Hence, the disposition of the proceeds is not testamentary in character. $^{\top}$ It is concluded that the fact that the proceeds are payable to a trustee subject to a trust should not make any material difference from an equitable point of view. ${ }^{8}$

${ }^{6}$ Burnet v. Wells, 289 U. S. 670, 679, 53 Sup. Ct. 76r, 764 (x933) ; Martin v. Modern Woodmen of America, 253 I11. 400, 97 N. E. 693 (I9I2) ; Johnston v. Scott, 76 Misc. 64I, 137 N. Y. Supp. 243 (IgI2); Matter of Haedrich, I34 Misc. 74I, 236 N. Y. Supp. 395 (1929), aff'd, 256 N. Y. 608 , I77 N. E. 160 (I93I); Fraser, supra note 4, at $3 \mathrm{I} ; 7$ Cooley, BRIEFS on Insurance (2d ed. I928) 6378; 2 Couch, Cyclopedia of Insurance Law (1929) 3306.

${ }^{7}$ See Johnston v. Scott, supra note 6 . The fact that death transfer taxes may be imposed upon insurance proceeds, subject to certain limitations, where the insured reserves a right to change the beneficiary under the policy [Chase National Bank v. United States, 278 U. S. 327,49 Sup. Ct. I26 (I929) ], does not refute the contention that such proceeds are not part of the insured's estate. The explanation of this lies in the nature of such taxes. They are not direct taxes upon property but excise taxes upon the transfer of property at the time of the decedent's death. The property may be part of the estate of the decedent but the exercise of this taxing power is not limited to such transfers. Such taxes are also imposed upon transfers of property no longer owned by the decedent at the time of his death where such transfers are related to his death, such as a transfer creating a joint tenancy [Tyler v. United States, 28I U. S. 497, 50 Sup. Ct. 356 (I930)], a gift in contemplation of death [United States v. Wells, 283 U. S. ro2, $5 \mathrm{I}$ Sup. Ct. 446 (r93I); Heiner v. Donnan, 285 U. S. 312,52 Sup. Ct. 358 (1932)], a transfer intended to take effect in possession or enjoyment at or after death [Guaranty Trust Co. v. Blodgett, 287 U. S. 509, 53 Sup. Ct. 244 (I933) ], a transfer in trust where the donor reserves a right to receive income until his death (see Guaranty Trust Co. v. Blodgett, supra), and a transfer in trust where the donor reserves a power to change the beneficiary of the trust, although the power does not extend to changes in favor of the donor or his estate [Porter v. Commissioner, 288 U. S. 436,53 Sup. Ct. 45I (1933)]. But even further, such taxes may be imposed upon a transfer of a power of control over property caused by the death of the donor resulting in the completion of a shifting to the donee of an economic benefit in certain property although such property may not have been part of the donor's estate. Thus in Chase National Bank v. United States, supra, the court held that Section 402 of the Revenue Act of Ig2I, imposing a transfer tax on proceeds of life insurance policies owned by the decedent on his own life payable to third parties, where power to change the beneficiary had been reserved to the decedent, was a legitimate exercise of this taxing power. The court recognized that the funds received by the beneficiary were not part of the estate of the decedent, and further held that the privilege of transferring property which constitutionally may be taxed as an excise, includes the transfer of property procured through expenditures by the decedent with the purpose, effected by his death, of having it pass to another. Cf. Lewellyn v. Frick, 268 U. S. 238,45 Sup. Ct. 487 (1925).

${ }^{8}$ See Matter of Haedrich, supra note 6 ; Penn Mutual Life Ins. Co. v. Hunt, 237 Mass. 24I, I29 N. E. 39 I (I92I). 
At first blush, it would seem that the foregoing argument should be sufficient. However, the frequency with which inquiry has been made of the writer for an opinion concerning this aspect of insurance trust settlements has been convincing evidence that there are elements involved which are misleading. The argument may not appear to be conclusive, as certain settlements of this type do seem to have some of the characteristics of a testamentary disposition and it may be argued that, while under modern social conditions there is a very strong public policy favoring payments made under ordinary life insurance contracts as a method of providing funds for the family of the insured after his death, nevertheless, this policy might not be extended to support arrangements of more complex nature affecting the disposition of such payments. Hence, further inquiry is necessary. Those settlements in which the problem appears to be the least serious will be considered first.

\section{(I) Irrevocable Unfunded Settlements Arising from Declarations or Agree-} ments Creating Immediate Trusts Affecting Title to the Policies

Irrevocable unfunded settlements arising from an irrevocable declaration by the settlor that he holds the policies in trust or from an irrevocable declaration or agreement coupled with an absolute assignment of the policies to a trustee may be classified under this heading. ${ }^{9}$ Assuming that the usual formalities for establishing a trust inter vivos are observed, so far as the writer is aware, no one would argue today that settlements of this type are of such testamentary nature as to require execution in accordance with the Statute of Wills. However, it is useful to inquire why the foregoing result is so readily acknowledged since analysis of the reasoning upon which this conclusion is based is of value in consideration of the other types of unfunded settlements.

A trust inter vivos may be created covering certain property, by the owner, the settlor, declaring himself trustee of it, or by transferring it to another person as trustee. The settlor must include in such declaration, or accompany such transfer by, a statement designating the purposes for which the trust is established, including a specific designation of the beneficiaries. In either case, if an equitable interest in the property is not acquired by the beneficiaries prior to the settlor's death, the transaction is testamentary in the sense that it will be considered invalid unless the requirements of the Statute of Wills are satisfied. The fact that the interest acquired by the

${ }^{\circ}$ The settlements included in this group and in subsequent groups are not the only settlements which might be established. There may be other types of settlements which might be created, but they are not discussed because they are exceedingly rare due to defects inherent in the particular type. For example, it might be possible to create an irrevocable unfunded settlement by means of an irrevocable declaration or agreement coupled with a revocable assignment of the policies to the trustee. Such a settlement would be most unusual and would probably give rise to a considerable amount of difficulty in operation because of the inconsistency between the declaration or agreement and the assignment of the policies. 
beneficiaries does not take effect in enjoyment or possession until the settlor's death does not alter this result. The failure of the beneficiaries to acquire an equitable interest may be caused, in the case of a declaration by the settlor, because there was no effective disposition of such interest by the settlor prior to his death; or in the case of a transfer to another person as trustee, because the settlor during his life did not make an effective conveyance to the trustee; or because, although the conveyance was effective, there was no effective disposition of such interest by the settlor prior to his death. ${ }^{10}$

Applying the foregoing principles to the irrevocable unfunded settlement described above, it seems clear that all of the essential formalities are performed. A chose in action may be held in trust; and since an insurance contract is merely a special type of chose in action, it is clear that the settlor may declare himself trustee of the policies without power of revocation or that he may irrevocably assign the policies to another person as trustee. In actual practice the latter situation is the more common. In either situation, it is clear that there is a definite res and that the beneficial interest in the policies vests in the beneficiaries prior to the settlor's death. Since the beneficial interest is vested irrevocably in the beneficiaries, it seems clear that in cases of this type the settlor intends to make and does make a present gift. This conclusion would not seem to be invalidated by the fact that the interest acquired by the beneficiaries does not take effect in enjoyment or possession until the settlor's death, since this element is inherent in the nature of the res and, as noted above, it has been held that this element in the case of an ordinary trust inter vivos is not necessarily fatal. The additional fact that there may be no active management of the res required of the trustee during the settlor's life ${ }^{11}$ and the fact that there is an automatic change in the res at the death of the settlor are not of sufficient importance to cause a distinction to be drawn. Further, the fact that the settlor might defeat the purpose of the trust by failure to pay premiums does not alter the result, since the cash surrender values, if payable to anyone, are payable to the trustee and not the settlor.

The foregoing conclusion with regard to settlements of this type is supported by several cases. ${ }^{12}$ Of these cases, Johnston $v$. Scott is of par-

${ }^{10}$ Scott, supra note 3 , at 521-544.

u The trustee may be called upon to perform active duties with respect to the policies. If the settlor fails to pay premiums, the trustee may be required to obtain loans on the policies or to surrender the same for cash or for conversion into paid-up policies. In the absence of a specific direction in the declaration or agreement, the trustee may be called upon to decide which of these various options shall be selected. The duty of selection is burdensome since such selection may result in a shifting of the major benefit of the trust from one group of beneficiaries to another.

${ }_{12}$ Johnston v. Scott, supra note 6 (assignment to a trustee); Penn Mutual Life Insurance Co. v. Hunt, supra note 8 (assignment to a trustee); Thompson's Ex'x v. Thompson, I90 Ky. 3, $226 \mathrm{~S}$. W. 350 (I920) (declaration by settlor); cf. Silvey v. Hodgdon, $52 \mathrm{Cal}$. 363 (I877) ; Burges v. New York Life Ins. Co., 53 S. W. 602 (Tex. Civ. App. I899); Jackson v. Hughes, 52 S. W. (2d) 687 (Tex. Civ. App. 1932). 
ticular interest. In this case it appeared that Scott executed two unfunded insurance trust agreements, in both of which he reserved a power of revocation and modification and also a power to change the beneficiaries on the policies which were made payable to Johnston, as trustee thereunder. Subsequently, Scott exercised his power to change the beneficiary of the policies, designating Johnston, in his individual capacity, as beneficiary thereof, and thereupon Scott irrevocably assigned all of the policies to Johnston, who, for value received, agreed that the proceeds of the policies should be charged with the same trust as provided in the trust agreement. Scott thereupon executed an instrument reciting the facts of the assignment and declaration by Johnston and stating that Scott surrendered his power to revoke or amend the said trust agreement. Deeds of assignment were delivered. It is not clear from the opinion who paid the premiums on the policies but they were not paid out of principal or income of the trust, as the court observes that all moneys involved in the trust were to be derived solely from insurance policies payable upon the death of the insured. Scott died shortly thereafter leaving a will which was admitted to probate.

Johnston brought suit to have the validity of the settlement determined. The settlement was attacked upon the ground that it was void as an attempt to dispose of Scott's estate by deed instead of by will in contravention of the Statute of Wills. The court held that there was no violation of the Statute of Wills and that the trust was valid upon the ground that the life insurance policies were not testamentary papers but were non-negotiable choses in action which were assignable; that the changes of beneficiary and assignments and renunciation of the right to revoke or modify operated to place a vested interest in Johnston; that all of the essential elements for a trust were present; and further, that Scott did not intend to avoid the Statute of Wills by this arrangement; that Scott was merely directing the use of the proceeds after his death; that he was not attempting to dispose of property by deed which was disposable by will; and that hence it was not a testamentary disposition. The court said:

"That the trust created was not to take effect in possession and enjoyment until the death of the settlor was because of the nature and source of the property and the terms of the deed, not because the deed or transaction was testamentary in character." 13

This case has been cited as authority supporting the validity of revocable unfunded settlements. ${ }^{14}$ There is some justification for this view. Since the final settlement, which was the one before the court, was actually made by Johnston on his declaration that he held the policies as trustee for the purposes set forth in the previous trust agreement, and since

${ }^{13}$ Johnston v. Scott, supra note 6 , at 647,137 N. Y. Supp. at 247.

is Note (1933) 46 HARV. L. REv. 8I8, 82I n. 22. 
the agreement contained a reservation of a power to revoke, it would seem possible to argue that Johnston intended his declaration to be revocable and that the statement by Scott purporting to relinquish the power to revoke contained in the previous agreement did not render the declaration made by Johnston irrevocable. If this reasoning is adopted, this case could be considered as authority for the revocable settlements.

On the other hand, it might well be argued that, in the light of all the facts, an intention is shown on the part of Johnston that his original declaration should be irrevocable or that even if it was revocable originally, the statement by Scott though inadvertently worded confirmed a subsequent intent on Johnston's part to relinquish that power. The learned court, in observing that the changes of beneficiary, assignments and renunciation of right to revoke by Scott operated to place a vested interest in Johnston, appears to follow the second line of reasoning. On this basis the writer is of the opinion that the case is properly classified as involving an irrevocable unfunded settlement coupled with an irrevocable assignment of the policies, and the conclusion that the settlement was not testamentary in nature will hardly be questioned.

\section{(II) Irrevocable Unfunded Settlements Arising from Declarations or Agreements Creating Immediate Trusts Not Affecting Title to the Policies}

Irrevocable unfunded settlements coupled with an irrevocable designation of the trustee as beneficiary may be sustained upon the reasoning which supports the settlements in the foregoing group. This is possible although the settlements differ from those in the foregoing group in two respects. In the first place, title to the policies does not pass to the trustee, who usually receives only a right to the proceeds payable on the death of the settlor. However, the right to receive such proceeds is a valuable right which vests irrevocably in the trustee during the settlor's life for the benefit of the trust beneficiaries and is a proper subject for a trust res. Hence, there is an immediate trust. It has been noted above that the result is not changed by reason of the fact that the interest of the beneficiaries cannot take effect in enjoyment or possession until the settlor's death. In the second place, under these settlements which do not involve assignment, if the settlor fails to pay premiums, the cash surrender values may be payable to the settlor, whereas under settlements in the first group such values, if payable to anyone, are payable to the trustee. However, in order to obtain such values, the settlor must prejudice his position in respect to the policies, and his action in taking such values does not result in his regaining the interest which vested in the trustee for the beneficiaries. Therefore, it seems that on principle, these elements of difference are insufficient to render such settlements testamentary in nature. 
Settlements of this type have been upheld by the courts. ${ }^{15}$ In one case the policy was payable to a designated beneficiary without indication of the existence of the trust in the designation, but the settlor indicated by oral declaration that he desired the beneficiary to pay the proceeds over to a third party ; $^{16}$ in other cases the policies were payable by their terms to a designated beneficiary in trust for other parties, there being little or no evidence otherwise as to the existence of the trust; ${ }^{17}$ and in one case, Kendrick $v$. Ray, ${ }^{18}$ there was a combination of the foregoing circumstances.

Since Kendrick $v$. Ray is the only one of the foregoing cases which mentions the testamentary question and as this case is frequently referred to in the cases hereinafter cited, it is of considerable interest. In this case it appeared that Kendrick held a policy on his life which was made payable "to and for the sole and separate use and benefit of E. A. Taft, trustee". It does not appear definitely in the report that Kendrick had a power to change the beneficiary of the policy. Kendrick notified Ray orally that Taft was to pay the proceeds over to Ray. On the death of Kendrick a sealed letter addressed to Taft was found among the deceased's effects directing Taft to pay over the proceeds to Ray. Kendrick's administrator brought this action to determine the ownership of the proceeds. The court handed down a decree in favor of Ray, the defendant, and this decree was affirmed on appeal, the court holding that a valid trust had been created. In arriving at this conclusion the court said:

"If we assume that the donor might have revoked the trust at any time during his life, he did not do so, and a power of revocation is not inconsistent with the existence of a valid trust.

"We discover nothing which rendered the trust invalid on grounds of public policy, or inoperative as an attempted testamentary disposition of property." 19

${ }^{25}$ Cables v. Prescott, 67 Me. 582 (1878) ; Kendrick v. Ray, I73 Mass. 305, 53 N. E. 823 (I899) ; Butler v. State Mut. L. Assurance Co., 55 Hun 2g6, 8 N. Y. Supp. 4rI (I8go), $a f f^{\prime} d, \mathrm{I} 25$ N. Y. 760,27 N. E. 409 (1891); In $v e$ Elting's Estate, 78 Misc. 692,140 N. Y. Supp. 238 (IgI2) ; Donithen v. Independent Order of Foresters, $209 \mathrm{~Pa}$. 170, 58 Atl. I42 (I904) ; Fidelity Title \& Trust $\mathrm{Co}$. of Pittsburg v. Graham, $262 \mathrm{~Pa} .273$, I05 Atl. 295 (Igr8); Finch v. Miller, I72 S. E. 25 (Ga. I933). See further Crews v. Crews' Adm'r, II3 Ky. 152, 67 S. W. 276 (I902); Catland v. Hoyt, 78 Me. 355,5 Atl. 775 (I886); Sell v. Steller, 53 N. J. Eq. 397, 32 Atl. 2I I (I895), modified, 55 N. J. Eq. 530, 37 Atl. IoIo (I897), which resemble the preceding cases with the added facts first, that it is not clear whether a right to change the beneficiary existed and, second, that the party receiving the proceeds was to pay a debt of the settlor before applying the proceeds to other purposes directed by the settlor. Such cases may perhaps not be properly classified as trust settlements as is pointed out hereinafter in the discussion relative to irrevocable settlements coupled with a revocable designation of beneficiary. Cf. Brett v. Warnick, 44 Ore. 5II, 75 Pac. 106r (I904).

${ }_{10}$ Donithen v. Independent Order of Foresters, supra note I5.

${ }^{17}$ See Cables v. Prescott (designated beneficiary in trust for third party); Butler v. State Mut. L. Assurance Co. (designated beneficiary "in trust for" third party); In re Elting's Estate (designated beneficiary "for express benefit of" third party) ; Finch v. Miller (designated beneficiary "as Trustee of" third party), all supra note I5.

${ }_{13}$ Supra note I5.

${ }^{10}$ Kendrick v. Ray, supra note 15 , at 310, 53 N. E. at 823, 824. 
The opinion does not indicate the facts which the court felt might justify the assumption that the settlor might have revoked the trust. The settlor does not appear to have reserved a power to revoke the trust unless it be assumed that the retention of the written declaration by the settlor and possession of the policy was equivalent to reservation of a power to revoke. Further, it should be noted that the settlor notified Ray orally of the existence of the trust and it would seem that a power to revoke should have been specifically set forth at that time to be effective. If Kendrick had a power to change the beneficiary designated in the policy, ${ }^{20}$ there might be a basis for considering that the transaction was revocable, but, as noted above, it is difficult to find justification for an assumption that Kendrick had power to change the beneficiary. The case, therefore, would seem to be properly classified as authority in support of an irrevocable unfunded settlement coupled with an irrevocable change of beneficiary, in which case the conclusion of the court that they could find nothing which rendered the trust invalid on grounds of public policy, or inoperative as an attempted testamentary disposition of property, would hardly be questioned.

\section{(III) Revocable Unfunded Settlements Arising from Declarations or} Agreements Creating Immediate Trusts Affecting Title to the Policies

Revocable unfunded settlements arising from a revocable declaration by the settlor that he holds the policies in trust or from a revocable declaration or agreement coupled with a revocable or irrevocable assignment of the policies to a trustee present little additional difficulty. In the case of an ordinary trust inter vivos, the weight of authority holds that the reservation of a power to revoke a declaration of trust or a conveyance in trust by the settlor does not make the settlement ambulatory in the testamentary sense. $^{21}$ This result is generally supported upon the theory that the reservation of a power to revoke does not negative an intent on the part of the

"See Note (1933) 46 Harv. L. Rev. 8I8, 821 n. 17, citing Kendrick v. Ray as a case involving a "revocable policy".

a Nichols v. Emery, rog Cal. 323, 4I Pac. I089 (1895) ; Booth v. Oakland Bank of Savings, I22 Cal. I9, 54 Pac. 370 (I898); Kelly v. Parker, I8I I1l. 49, 54 N. E. 6I5 (I899); Lewis v. Curnutt, I30 Iowa 423, I06 N. W. 914 (1906); Stone v. Hackett, 78 Mass. 227 (I858) ; Jones v. Old Colony Trust Co., 25r Mass. 309 , I46 N. E. 716 (I925) ; Roche v. Brickley, 254 Mass. 584, 150 N. E. 866 (I926) ; Wilcox v. Hubbell, r97 Mich. 2I, I63 N. W. 497 (I9I7); Smith v. Corey, I25 Minn. I90, I45 N. W. I067 (I9I4); Van Cott v. Prentice, 104 N. Y. 45, 10 N. E. 257 (1887); Windolph v. Girard Trust Co., 245 Pa. 349, 91 Atl. 634 (I9I4) ; Dolan's Estate, 279 Pa. 582, I24 Atl. 176 (I924). Contra: Gilham v. Mustin, 42 Ala. 365 (1868); Mathias v. Fowler, I24 Md. 655, 93 Atl. 298 (I915) ; Nutt v. Morse, I42 Mass. I, 6 N. E. 763 (1886); McEvoy v. Boston Five Cents Savings Bank, 201 Mass. 50, 87 N. E. 465 (Igog); Russell v. Webster, 213 Mass. 49I, roo N. E. 637 (I9r3) ; Citizens Nat. Bank v. McKenna, I68 Mo. App. 254, I53 S. W. 21 (Ig13); Worthington v. Redkey, 86 Ohio St. 128, 99 N. E. 2I I (I9I2) ; Providence Institution for Savings v. Carpenter, I8 R. I. 287, 27 Atl. 337 (1893) ; Ellis v. Pearson, I04 Tenn. 59I, 58 S. W. 3 I8 (1900) ; Carlton v. Cameron, 54 Tex. 72 (I880); Warsco v. Oshkosh Savings \& Trust Co., I83 Wis. I56, Ig6 N. W. 829 (I924); cf. Union Trust Co. v. Hawkins, I21 Ohio St. I59, I67 N. E. 389 (1929). For further digest of authorities, see Note (I93I) 73 A. L. R. 209; Scott, supra note 3 , at $522-544$. 
settlor to make a present gift since title to the property vests in the trustee for the use of the beneficiaries at the time of the declaration or conveyance subject to divestment by exercise of the reserved power. ${ }^{22}$ In the case of the insurance settlements falling in this group, the policies constitute the res as in the irrevocable settlements first discussed. Since the reservation of a power to revoke in the case of ordinary trusts inter vizos does not make the settlements testamentary, the reservation of such power in an insurance settlement where the policies are held in trust should not cause a different conclusion to be reached unless the fact that insurance policies are involved introduces a new element not previously considered.

It has been noted above in the case of irrevocable settlements that the interest of the beneficiaries does not take effect in enjoyment or possession until the settlor's death, that there may be little or no active management required of the trustee, and that there will be an automatic change in the res at the death of the settlor; but these characteristics do not make such settlements testamentary. ${ }^{23}$ Since this is the case, it would seem that these characteristics should not be sufficient to cause a different result to be reached here. It is true that the settlor might defeat the purpose of the trust by failing to pay premiums and in the present case he could obtain the cash surrender values even though they were paid to the trustee, but this fact loses much of its significance when we observe that, in the case of the ordinary trust inter vivos, the fact that the settlor may withdraw a part or all of the principal of the trust does not necessarily make the settlement testamentary in character. It seems, therefore, that the fact that insurance policies constitute the trust res does not require a different conclusion from that reached in the case of the ordinary trust inter vivos.

There is persuasive authority supporting the foregoing conclusion. Thus, in Matter of Voorhees, ${ }^{24}$ the insured held policies on his life payable to his estate, power to change the beneficiary of the policies being reserved thereunder. The insured assigned the policies to a trustee under a deed of trust reserving a right under the deed to revoke the same and to receive distributive shares of surplus under the policies. The insured also reserved a right to pay premiums on the policies and to receive dividends. Thereafter the insured died and the trustee collected the proceeds for administration in accordance with the terms of the trust instrument. The New York tax law then in force provided for a transfer tax on property passing by will or intestacy or on a gift made in contemplation of death or intended to take effect in possession or enjoyment at or after death. The Surrogate in assessing the tax did not include insurance proceeds collected by the trustee

c Hence it is immaterial whether the assignment is revocable or irrevocable. In either case, when the declaration or agreement is revocable, the trustee receives a vested interest subject to divestment.

${ }^{2}$ Supra p. 704.

as 200 App. Div. 259, I93 N. Y. Supp. 168 (Ig22). 
as property subject to tax. The State Tax Commission appealed, and the order of the Surrogate was affirmed on the ground that the insurance proceeds payable to the trustee never came into the insured's estate. On this basis it was concluded that the proceeds were not taxable as passing by will or by intestacy and that the transfer was not testamentary in character; and further, that the assignment of the policies did not constitute a gift in contemplation of death or intended to take effect in possession or enjoyment at or after death in any sense within the meaning of the statutes. The court observed that the reservation of rights under the deed of trust did not affect this conclusion.

In the previous discussion relative to irrevocable settlements, Johnston v. Scott ${ }^{25}$ was considered, and it was pointed out that there was a possible argument that the settlement involved in that case was revocable. ${ }^{26}$ If this argument could be sustained, the case should be classified with the revocable settlements of the type presently under discussion. In that event, since the court in that case sustained the settlement, this case could also be considered as authority supporting the validity of the third type of settlement.

Frost $v$. Frost ${ }^{27}$ is an interesting case in this connection. Here it appeared that the insured owned insurance policies which were payable to his legal representatives and that he executed an assignment purporting to convey the policies to "the trustees to be named in my will" for the use of his wife. Subsequently, the insured died leaving a duly executed will naming executors and trustees but not specifically mentioning the policies. His widow brought suit against the executors and trustees to recover the proceeds; recovery was denied on the ground that the disposition of the policies was testamentary. This conclusion was sound since the insured had made no declaration of trust under which he purported to hold the policies as trustee and he did not transfer the policies to trustees during his life. Since the disposition was testamentary and since the will did not direct disposition of the policies or any interest thereunder, the formalities required by the Statute of Wills had not been met. It is submitted that the case is easily distinguishable from the two foregoing cases in that a trust was not immediately created and that this case, therefore, may not be considered as authority adverse to the validity of revocable unfunded insurance settlements where a trust is immediately created.

\section{(IV) Settlements Arising from Unfunded Bilateral and Unilateral Con- tracts Not Affecting Title to the Policies}

Settlements included in this group may arise from various types of unfunded bilateral or unilateral contracts, the contract in each case being

Es Supra note 6.

${ }^{3}$ Supra pp. 705, 706.

${ }^{27} 202$ Mass. 100, 88 N. E. 446 ( 1909 ). 
coupled with a revocable designation of a trustee as beneficiary under the policies. The first type to be considered is the unfunded bilateral contract in which the settlor does not reserve a power to revoke the agreement. For reasons which will be apparent in the following discussion, this arrangement is sometimes referred to as an irrevocable unfunded settlement.

The question may well be asked why irrevocable unfunded settlements involving a revocable designation of a trustee as beneficiary should be considered, since the arrangement is obviously inconsistent and should be avoided because of the difficulties which may arise. There are two very good answers to this query. In the first place, while almost no formal settlements of this type are established, from the number of cases which have come before the courts involving settlements of this type it must be assumed that a large number of such settlements are made informally by the insured naming a beneficiary, or more often by his refraining from changing the beneficiary under a policy in reliance upon the oral or written promise of such beneficiary to receive the proceeds payable on the death of the insured for certain stipulated purposes. In the second place, these settlements appear to be the direct forerunner of the modern revocable unfunded insurance trust settlement.

At first blush, the testamentary problem presented by these settlements does not seem to differ from the problem involved in the case of the ordinary life insurance policy where no settlement is made. Since an insurance contract apart from a trust settlement need not be executed in conformity with the requirements of the Statute of Wills, irrespective of whether or not various powers, including a power to change the beneficiary of a policy, are reserved, ${ }^{28}$ it has been argued that there is no testamentary problem involved. ${ }^{29}$ This position is strengthened by the further argument that since the settlement arises from a contract between the settlor and the trustee, the creation of such a settlement gives rise to an implied covenant on the part of the settlor not to change the beneficiaries under the policies. If this argument could be sustained, cases of this type might be included with the irrevocable unfunded settlements classified in the second group. However, when the entire arrangement is carefully scrutinized, some doubt arises with respect to the foregoing analysis.

There are two theories regarding the nature of the interest acquired by the insurance beneficiary who has been named under a revocable designation. The minority view holds that the beneficiary in such a case receives a vested interest subject to divestment, ${ }^{30}$ and on this basis the foregoing

${ }^{c 5}$ See supra note 6.

¿see Note (I933) 46 HARv. L. Rev. 818, 822 n. 23.

to Johnson v. New York Life Ins. Co., 56 Colo. I78, I38 Pac. 414 (I9I4); Indiana Nat. Life Ins. Co. v. McGinnis, 180 Ind. 9, IOI N. E. 289 (I9I3); VANCE, HANDBOoK of THE LAW of INSURANCE (2d ed. I930) $561-562$. For further digest of authorities, see 37 C. J. 580 n. 6 I. 
argument is strengthened. However, the weight of authority is definitely to the effect that such beneficiary has only an expectancy. ${ }^{31}$ Since an expectancy may not be held in trust, ${ }^{32}$ it is difficult to find a res until the death of the settlor. On considering the foregoing analysis, persons who are not well acquainted with the legal nature of life insurance contracts are apt to conclude that the testamentary rule which requires completion of a gift before the death of the donor, when applied to this situation, invalidates the transaction if the requirements of the Statute of Wills are not met, since, under the foregoing reasoning, the gift is not complete prior to the donor's death. This view is based upon the assumption that life insurance policies are like other choses in action, particularly corporate municipal or government bonds, and it loses sight of the fact that life insurance contracts have a peculiar character of their own which is reflected in the law.

Bonds of the above type and life insurance policies are apt to have a superficial physical resemblance to each other and legally both evidence a chose in action, but here the resemblance largely ceases. Ordinarily such bonds, unless registered, are negotiable; a life insurance policy is not negotiable although title thereto may be conveyed by the owner to another person. In the case of a negotiable bond, the obligor undertakes to pay a sum certain with interest to the holder thereof on maturity which is usually a specified date; but in the case of an ordinary life insurance policy, the insurer undertakes to pay a sum certain upon the insured's death to a third party, who may or may not be the insured's legal representative, as designated by the insured. Both the bond and the policy are an asset of the owner; but whereas the bond continues to have a value to the owner's estate after his death, the insurance policy, when payable to a third party who is not a legal representative of the insured, has no such value to the insured's estate and the sum paid to the third party beneficiary is never part of the deceased's estate. ${ }^{33}$

In the case of an outright gift of an ordinary negotiable bond, legal title must pass to the donee during the life of the donor. If this is not done, the gift will be invalid unless the requirements of the Statute of Wills are satisfied. The same rule would apply if the gift was to a trustee in trust

3. VANCE, op. cit. supra note 30 , at $56 \mathrm{I} ; 7$ COOLEY, op. cit. supra note 6 , at $6406 ; 2$ JoYCE,

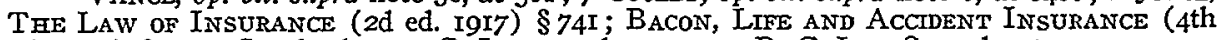
ed. 1917) \$379. See further 37 C. J. 579 and notes; I4 R. C. L. I3 87 and notes.

${ }^{2}$ Matter of Gurlitz, I05 Misc. 30, I72 N. Y. Supp. 523 (19I8), aff'd, sub nom. Matter of Iynde, I90 App. Div. 907 , I79 N. Y. Supp. 933 (I919); Scott, supra note 3, at 528 1. I9; TRusts Restatement (Am. L. Inst. 1930) Tentative Draft No. I \$ 74.

${ }^{33}$ See supra note 7 , where it is pointed out that the fact that death transfer taxes may be imposed upon insurance proceeds, subject to certain limitations, where the insured reserves the right to change the beneficiary under the policy does not refute the contention that such proceeds are never part of the insured's estate when payable to a person other than his executor or administrator. 
for the benefit of others. Since the donor in either case holds title to the bond at the time of his death, he may pass title to a donee at that time only in a manner which will satisfy the requirements of the Statute of Wills since the statute is intended to cover cases of exactly this type. The same rule applies with respect to the passage of title to an insurance policy. But the passage of title to an insurance policy must be clearly distinguished from the power to designate a third party as a beneficiary to receive the proceeds thereof at or after the death of the insured. The designation of a third party to receive the proceeds when not coupled with a trust settlement admittedly is not a testamentary act which requires compliance with the Statute of Wills, and it was noted above that a reservation of a power to designate another party as beneficiary does not alter this result. Since this is so, it has been observed ${ }^{34}$ that the testamentary problem in the case of an irrevocable unfunded settlement coupled with a revocable designation of a trustee as beneficiary clearly reduces itself to a question of whether the insured may make a bilateral contract with the designated beneficiary in regard to the disposition of insurance proceeds when received by the beneficiary without observing the formalities required by the Statute of Wills.

The great weight of authority supports such contracts, although testamentary formalities are omitted. ${ }^{35}$ In some cases the insurance proceeds were payable to a person within the class permitted under the rules of the society or under the terms of the insurance contract for the benefit of a person not within the permitted class, but even so the settlement was en-

"See Fraser, supra note 5 , at 7728 .

"Christensen v. Christensen, I4 F. (2d) 475 (D. C. N. Y. I926); Ambrose v. United States, I5 F. (2d) 52 (D. C. N. Y. I926), (r927) 40 HARv. L. REV. 785; Lashley v. Lashley, 2 I2 Ala. 255, IO2 So. 229 (I924), but see same case subsequent trial, 2I9 Ala. 3I2, x22 So. 314 (1929); Peek's Ex'r v. Peek's Ex'r, IQI Ky. 423, 4I S. W. 434 (I\&97), but see same case subsequent trial, 50 S. W. 982 (I899); Clark v. Callahan, 105 Md. 600, 66 At1. 6 I8 (1907); Coyne v. Supreme Conclave of Improved Order of Heptasophs, Io6 Md. 54, 66 Atl. 704 (Ig07); Mee v. Fay, Ig0 Mass. 40, 76 N. E. 229 (Ig06); Cowin v. Hurst, I24 Mich. 545, 83 N. W. 274 (1900); Grand Lodge A. O. U. W. of Mich. v. Beath, r50 Mich. 657, II4 N. W. 662 (Ig08); Alexander v. Sovereign Camp etc., I93 Mo. App. 4II, I86 S. W. 2 (Igr6); Estate of Devries v. Hawkins, 70 Neb. 656,97 N. W. 792 (Ig03); Hirsh v. Auer, I46 N.'Y. I3, 40 N. E. 397 (I895); Dorland v. Whitmer, 43 Ohio App. 285,182 N. E. 686 (I932); Schomaker v. Schwebel, 204 Pa. 470, 54 Atl. 337 (1903); Waterhouse v. Waterhouse, 29 R. I. 485, 72 At1. 642 (Ig09); Mellville v. Wickham, I69 S. W. II23 (Tex. Civ. App. IgI4); Rape v. Gardner, 54 S. W. (2d) 594 (Tex. Civ. App. I932); Hurd v. Doty, 86 Wis. I, 56 N. W. 37 I (1893). Contra: Staples v. Murray, 124 Kan. 730, 262 Pac. 558 (1928). Cf. Fisher v. Donovan, 57 Neb. $36 \mathrm{r}, 77$ N. W. 778 (1899); Katz v. Witt, 74 Misc. 582, I34 N. $\mathrm{Y}$. Supp. 675 (19rI).

If settlements of the above type involving a promise on the part of the trustee or the trust beneficiary to pay premiums are not considered as being funded settlements, they should be included here. See Wrather v. Stacy, 26 Ky. L. R. 683, 82 S. W. 420 (I904), and Kerr v. Crane, 212 Mass. 224,98 N. E. 783 (19I2).

See further the following cases, where it is not clear whether or not the settlor could change the beneficiary designated in the policy: Crews v. Crews' Adm's; Catland v. Hoyt; Sell v. Steller; Fidelity Title and Trust Company of Pittsburgh v. Graham; Brett v. Warnick, all supra note 1.5 . 
forced. ${ }^{36}$ But there are cases to the contrary, ${ }^{37}$ and there are other cases where recovery was not permitted upon the ground that the evidence introduced was insufficient to establish a trust. ${ }^{38}$

In the great majority of the cases cited above there was no comment concerning the testamentary nature of the contracts or settlements, ${ }^{39}$ and yet with few exceptions, they were sustained. In a number of these cases this result was attained through an action at law on the contract, ${ }^{40}$ but in several cases where action was brought at law, the court indicated that the action, though falling under the common law class of assumpsit, either was in the nature of a bill in equity ${ }^{41}$ or might more properly have been brought as a bill in equity to enforce a trust. ${ }^{42}$ In other cases recovery was sought directly through a bill in equity to enforce a trust ${ }^{43}$ or through other forms of equitable suit. ${ }^{4+4}$

It should be noted that in a number of the cases cited, the person in the position of trustee was also a creditor of the insured, a common arrangement being that the creditor would collect the proceeds, pay the debt and turn over the balance to other designated parties. ${ }^{45}$ In other cases the

${ }^{3}$ Peek's Ex'r v. Peek's Ex'r; Clark v. Callahan; Coyne v. Supreme Conclave Improved Order of Heptasophs; Kerr v. Crane; Cowin v. Hurst, all supra note 35 . Cf. Grand Lodge A. O. U. W. of Mich. v. Beath; Katz v. Witt; Mellville v. Wickham; Hurd v. Doty, all supra note 35 ; see also In re Danville Hotel Co., 33 F. (2d) I62, I75 (D. C. I1l. I929).

${ }^{37}$ O'Brien v. Massachusetts Catholic Order of Foresters, 220 Mass. 79, I07 N. E. 400 (1915); O'Brien v. Grand Lodge A. O. U. W. of Mass., 223 Mass. 237, III N. E. G55 (I9I6); Carpenter v. Knights of Columbus, 239 Mass. 287, I3I N. E. 863 (I92I); Cessna v. Adams, 93 N. J. Eq. 276, Ir5 Atl. 802 (I92I).

${ }^{3}$ Lashley v. Lashley, supra note 35 ; Scott v. Miller, I79 Ark. 7, I3 S. W. (2d) 8ig (1929) ; Union \& New Haven Trust Co. v. Koletsky, I67 At1. 803 (Conn., I933) ; Bliss v. Bliss, 20 Idaho 467, II9 Pac. 45I (IgII) ; see also Cessna v. Adams, supra note 37, where the court refused to enforce the settlement on the ground that the trust beneficiary was not within the permitted class and further upon the ground that even though the trust beneficiary had been within the permitted class, the evidence introduced was insufficient to prove the existence of a trust settlement.

In Scott v. Miller, supra, the rule of evidence for establishing a trust of this type is defined. It is stated that the general preponderance rule does not apply but that a rule requiring clear, convincing and satisfactory evidence will be applied.

${ }^{39}$ The testamentary problem is briefly mentioned in Mee v. Fay and Kerr v. Crane, both supra note 35 . In each of these cases the court concluded that the settlement was not testamentary in nature. In Staples v. Murray, supra note 35 , the opposite conclusion was reached, but with three judges dissenting in a strong minority opinion.

${ }^{20}$ See Peek's Ex'r v. Peek's Ex'r; Wrather v. Stacy, both sitpra note 35; Catland v. Hoyt, supra note 15; Mee v. Fay; Estate of Devries v. Hawkins; Hirsh v. Auer, all supra note 35 ; Fidelity Title \& Trust Co. of Pittsburgh v. Graham, supra note 15; Waterhouse v. Waterhouse; Mellville v. Wickham; Rape v. Gardner, all stipra note 35.

31 Estate of Devries v. Hawkins, supra note 35.

2 Wrather v. Stacy; Mee v. Fay, both supra note 35.

${ }^{13}$ See Christensen v. Christensen; Ambrose v. United States; Lashley v. Lashley; Clari v. Callahan; Coyne v. Supreme Conclave of Improved Order of Heptasophs; Kerr v. Crane, all supra note 35; Sell v. Steller, supra note 15; Dorland v. Whitmer; Hurd v. Doty, both supra note 35 .

${ }^{4}$ See Crews v. Crews' Adm'r (action to settle estate), supra note 15; Cowin v. Hurst (bill to enjoin collection of draft); Grand Lodge A. O. U. W. of Mich. v. Beath (bill to determine ownership of funds); Schomaker v. Schwebel (bill to recover insurance proceeds), all supra note 35 ; Brett v. Warnick (bill for specific performance of contract), supra note I5.

${ }^{25}$ For cases of this type, where recovery was sought on the contract in an action at law, see Wrather v. Stacy, sipra note 35; Catland v. Hoyt, supra note 15. For cases where recovery was sought by a suit in equity, see Crews v. Crews' Adm'r, supra note I5; Alexander v. Sovereign Camp etc., supra note 35. 
trustee agreed to pay a debt of the insured out of the insurance proceeds to a third party who was a creditor of the insured and to turn over to other designated parties the balance of the proceeds. ${ }^{46}$

Objections might be raised against the use of the foregoing cases in a discussion of express trusts. It is sometimes argued that in many of these cases the trustee acts merely as a conduit for payment of the funds, there being no active duties other than to receive the proceeds and pay them over to designated parties. However, an insurance beneficiary usually must perform certain acts before he can obtain possession of the proceeds. Moreover, the payment of the funds by the trustee to the trust beneficiaries may well require considerable activity on the part of the trustee and some time may elapse before payment can be made. It would seem that the duties and responsibilities involved may well be sufficient to refute this argument.

A second and more serious objection is that in the foregoing cases involving payment of a debt and even in cases where no debt is involved, the person who in good conscience is entitled to the proceeds brings suit against the beneficiary designated in the policy, seeking by this means to impress a trust upon the proceeds by operation of law to prevent unjust enrichment. However, it should be observed that in a number of the cases the courts do not follow this line of reasoning but clearly base their decisions on the theory that a valid express trust exists. ${ }^{47}$

We have observed that in all of these cases, if the weight of authority is followed, there is not an immediate settlement but a contract for the creation of a trust which will arise in the future. The parties to a contract can mutually agree to cancel it and it would seem that the fact that a contract by its terms calls for the creation of a trust in the future would not operate to prevent a cancellation by the parties provided cancellation takes place prior to the creation of the trust, at which time the interest of the beneficiaries becomes vested. It would seem, therefore, that these arrange-

${ }^{16}$ For cases of this type where recovery was sought on the contract in an action at law, see Fidelity Title \& Trust Co. of Pittsburgh v. Graham, supra note I5; Rape v. Gardner, supra note 35 .

For cases of this type where recovery was sought by a suit in equity, see Grand Lodge A. O. U. W. of Mich. v. Beath, supra note 35; Sell v. Steller; Brett v. Warnick, both supra note 15; Hurd v. Doty, supra note 35.

It would seem that the promise of the trustee in cases of the foregoing type does not involve a payment from personal funds of the trustee but from specific funds held in trust and hence although such promise may be oral it should not be considered as being invalid because of the provision of the Statute of Frauds relating to a promise made to pay the debt of another. See I WIIIISTON, CoNTRACTS (I920) $\$ \$ 459,460$. The question appears to have been raised in only one case. See Fisher v. Donovan, supra note 35. But there may be a provision in the statute to the effect that a contract to establish a trust must be evidenced by a memorandum in writing subscribed by the party to be charged therewith. See New York Personal Property Law (I9I7) \& 3I, as amended by N. Y. Laws I933, c. 6I6. Under a statute containing a provision of this character an oral agreement of the general type under consideration would be void even though the payment of a debt was not involved.

${ }^{4}$ See supra note 43. 
ments are in fact revocable prior to the death of the insured. That this is the intention of the parties is illustrated by the fact that the insured retains a power to change the beneficiary under the policy. In certain cases there are particular facts involved which give further indication of such an intent. Thus, where the trustee agrees to pay a debt of the insured out of the proceeds, it seems clear that the parties intend that if the debt is satisfied prior to the insured's death, the agreement will be cancelled. Even in those cases not involving a debt there may be circumstances which establish an intent on the part of the parties to cancel the arrangement at a later date. Although the parties may cancel the contract, there is nevertheless a binding agreement and under the foregoing decisions, when a trust arises as a result of such agreement, the disposition involved will be sustained.

But suppose that the contract could be revoked by one of the parties without the consent of the other party, would a trust arising from such an arrangement also be held valid? The so-called "revocable unfunded insurance trusts" which have come into common use in the last few years, are of this type. These arrangements are usually evidenced by a formal instrument executed by both the insured and the insurance beneficiary in which it is provided that after the insurance beneficiary receives proceeds on the death of the insured, such beneficiary shall hold the proceeds in trust for certain purposes. The insured expressly reserves a power to amend or revoke the arrangement and also power to exercise various rights reserved to him by the terms of the policy including the right to change the beneficiary thereunder. Various routine provisions relating to management of the trust fund are included. In some instances, in addition to the foregoing provisions, the insured specifically agrees to pay premiums.

If the minority view that an insurance beneficiary receives a vested interest subject to divestment when a right to change the beneficiary is reserved is followed, it would seem that even in these modern arrangements, an immediate trust is created, ${ }^{48}$ and may be sustained upon the same theory as the revocable unfunded settlements of the third group discussed above; ${ }^{40}$ but if the opposite view, which is supported by the weight of authority, is followed, ${ }^{50}$ further consideration is necessary.

If the insured has covenanted to pay premiums, it has been argued that a bilateral contract is created and that the insured by reserving a power to revoke the agreement at will does not invalidate it since many contracts stipulate that they may be cancelled at the option of a particular party or parties. ${ }^{51}$

\footnotetext{
¿s See supra note 30.

${ }^{49}$ See supra p. 708 et seq.

${ }^{\infty}$ See supra notes 31 and 32.

${ }^{2}$ Fraser, supra note 5 , at 7726 .
} 
An opinion to the contrary, however, would not appear to be fatal as it merely reduces the question to that presented by more common arrangements in which the insured does not covenant to pay premiums. In such cases it would seem that the agreement, insofar as it relates to the proceeds of the policies when taken as a whole, simply evidences an offer by the insurance beneficiary to the insured to the effect that the beneficiary will act as trustee on and after the death of the insured with respect to proceeds received if the insured will pay the premiums on the policies until his death. The covenant of the insurance beneficiary usually is not a covenant to make a declaration of trust with respect to the proceeds when they are received, although the contract might so provide, but rather the covenant is such that upon the death of the insured the trust arises automatically, first with regard to the then-vested right to receive the proceeds, and second with regard to the proceeds when received. This arrangement usually is not set forth in express terms, but necessarily results from the various covenants contained in the contract.

The fact that the agreement may provide for deposit of insurance policies with the trustee would not seem to affect the foregoing conclusion since the policies are not assigned to the trustee. The provision covering deposit of the policies appears to be an independent contract for a bailment which legally is not an essential element of the principal contract relating to the insurance proceeds but which, for practical reasons, is included as a part thereof. ${ }^{52}$ It seems, therefore, that when the insured does not covenant to pay premiums, a binding unilateral contract is created upon the death of the insured and that a trust arises at that time.

Various unfunded arrangements of the modern type have been considered by the courts, but it is not possible in all cases to classify them definitely as bilateral or unilateral transactions because all the facts necessary to such a determination are not always reported. The revocable bilateral transaction appears to have been considered first in Fagan $v$. Bugbee. ${ }^{53}$ In this case it appeared that the insured and the corporate fiduciary executed a revocable unfunded insurance trust agreement in which the insured agreed to pay the premiums. The insured reserved a power to revoke the agreement and also power to exercise various rights reserved under the terms of the policies including a right to change the beneficiary thereof. The trustee was named beneficiary of the policies which were deposited with it. After the death of the insured the trustee collected the proceeds and a transfer $\operatorname{tax}$ was assessed upon the proceeds on the theory that the transaction amounted to a transfer intended to take effect in beneficial possession or enjoyment at or after the death of the settlor within the meaning of the New Jersey transfer tax statute.

co5 N. J. L. 85, I43 Ati. 807 (I928). 
The court upheld the tax on the ground that the transfer of the insurance proceeds by the trustee, not the transfer to the trustee by the insurer, was taxable as a transfer intended to take effect in possession or enjoyment at or after the death of the settlor. The court admitted that if the proceeds had been payable directly to beneficiaries there would be no tax, but was of the opinion that the insertion of a trustee made a material difference on the ground that if the proceeds had been made payable to the insured's estate and had thereafter passed to beneficiaries under the terms of his will the proceeds would have been taxable, and that the present transaction was closely analogous to that situation. The court did not observe that in the case where proceeds are payable to the insured's estate such proceeds become in fact part of the estate, whereas in the case of payment of proceeds directly to named beneficiaries, such proceeds are at no time part of the insured's estate. Other than as above stated, there was no discussion of the testamentary question. ${ }^{54}$

This position does not appear to have been favorably received: the New Jersey Legislature promptly passed an act exempting life insurance proceeds payable to a trustee for the benefit of named beneficiaries from transfer taxes. ${ }^{55}$ A similar statute was adopted in Pennsylvania. ${ }^{56}$

Myers' Estate ${ }^{5 \tau}$ is of considerable interest in this connection. In this case it appeared that the insured executed a revocable unfunded insurance trust agreement under which all rights in the policies were reserved to the insured, the trustees being designated as beneficiaries under the policies. ${ }^{5 s}$ The agreement provided that the trustee should dispose of the proceeds in accordance with the provisions of the settlor's will. At the time the agreement was executed, the insured also executed a will without specifically mentioning the trust agreement. The insured died eight days later and the trustees collected the proceeds. A transfer inheritance tax was levied on the proceeds on the theory that the transaction amounted to a transfer by

of Cf. Matter of Haedrich, supra note 6.

*o N. J. Comp. STAT., SupP. (I93I) § 208-537.

o PA. STAT. ANN. (Purdon, I930) tit. 72, \$2301. For other states which have adopted similar legislation, see Robinson, Saving Taxes in Drafting Wills and Trusts (2d ed. 1933) I94-I95.

${ }^{67} 309$ Pa. 58I, I64 At1. 6II (1933).

as This description of the agreement appears to be justified despite the observation of the court that the "deceased executed a trust of six insurance policies" and the further fact that there is no comment in the report with regard to payment of premiums. The court states that "the deed of trust recites that it was made for the purpose of settling and securing the proceeds of the policies ..... It further appears from the opinion that the insured reserved a right to change the beneficjary of the policies, to obtain loans, to receive shares of surplus, to receive dividends, to receive all other cash payments, to surrender and receive the cash surrender value of the policies and on maturity thereof prior to his death, to collect the proceeds free of the trust. The reservation of these rights is not consistent with an assignment of the policies; hence it seems certain that there was no assignment of the policies.

It seems fairly clear that there was no property other than insurance proceeds involved; hence it can be concluded that the trustees were not to pay insurance premiums. Whether the insured agreed to pay premiums or not is not stated. It is expressly stated that the insured reserved the right to revoke the agreement. 
deed to take effect after death. The parties opposing the assessment of the tax argued that the proceeds were not taxable as the transaction fell within the exemption established under the above-mentioned statute. ${ }^{59}$ The lower court $^{60}$ adopted this argument and held that the tax was improperly assessed, but on appeal judgment was reversed on the ground that the provisions of the statute required that the trust beneficiaries should be named definitely in the trust agreement during the lifetime of the settlor, and that if this was not done, the arrangement would be considered merely as an attempt to evade taxes. ${ }^{61}$

It has been pointed out above that cases which sustain the validity of a death transfer tax upon insurance proceeds when they are paid to a revocably designated beneficiary other than the insured's estate do not refute the contention that such proceeds are not part of the estate of the insured. ${ }^{62}$ Further, certain transfers which take place before or upon the death of a donor may have elements in them which render such transfers sufficiently testamentary to permit the assessment of a death transfer tax upon the property involved without being of such testamentary character as to require the transfer to be evidenced by a written instrument executed in a manner which complies with the Statute of Wills. This is true with respect to gifts in contemplation of death, or gifts intended to take effect in possession or enjoyment at or after death. There would seem to be no reason for reaching a different conclusion in cases involving merely a transfer of a power of control with respect to property not constituting an asset of the deceased's estate. Hence, cases such as Fagan v. Bugbee and Myers' Estate may not be considered as being directly in point on the particular testamentary problem which is the subject of the present discussion.

The foregoing conclusion is supported by Sacred Heart Church $v$. Fidelity Trust Co. ${ }^{63}$ and Bose v. Meury. ${ }^{64}$ In the first of these cases, it appeared that Morris Rosenblum on October 9th, I928, entered into a revocable life insurance agreement with a corporate fiduciary. The agreement provided in part as follows:

"The assured reserves the right to withdraw any of the policies or any sums of money or securities deposited at any time hereunder, and further reserves the right to revoke this instrument and the trusts herein provided for, and upon such withdrawal and revocation, the trustee shall deliver said policies, money or securities as may be directed by the assured. The right to change the beneficiaries under this trust is reserved by the assured, it being intended that none of the beneficiaries shall receive any vested interest in the trust herein provided

${ }^{\infty}$ See supra note 56 .

क Myers' Estate, I6 Dist. \& C. 533 (Pa. 1932).

a Cf. Katz v. Witt, supra note 35 .

"See supra note 7.

${ }^{\infty}$ I6 Dist. \& C. 66I (Pa. I93I).

at II N. J. Eq. 62, 163 At1. 276 (1932). 
for, or in the policies, money or securities now or at any time deposited hereunder, unless this trust shall remain unrevoked at the time of the death of the assured." 65

The agreement provided further that on the settlor's death, the trustee should collect the insurance proceeds and pay therefrom specific sums totalling $\$ 5,000$ to certain charitable institutions, and that the balance should be held in trust. The settlor deposited insurance policies on his life having a face value of $\$ 105,000$ with the trustee. It appears from the report that money and securities were deposited by the settlor with the trustee. Whether the income from such securities was to be used to pay premiums is not stated in the report. Three days later the settlor died and the proceeds were collected by the trustee, which refused to make payments to the charitable institutions on the ground that the provision for such payments constituted a conveyance of personal estate in trust executed less than one calendar month prior to the death of the settlor, and was therefore void under the statute prohibiting such transfers unless supported by consideration. ${ }^{66}$ The charitable institutions filed a bill in equity to compel payment of the designated sums by the trustee. The court held that the agreement was valid since there was no conveyance of personal estate of the insured, and that hence the charitable institutions were entitled to the sums specified. This case was not referred to by the court in Myers' Estate.

A question might be raised as to the propriety of classifying this case as one involving an unfunded settlement. In the absence of a definite statement in the report of the case with regard to payment of premiums, it seems that the case should at least be considered in the discussion of cases of the unfunded type since there may have been no direction to use income to pay premiums in which case, so far as insurance policies are concerned, the settlement may be considered unfunded.

In Bose v. Meury, the second case cited above, it appeared that Meury, the insured, while insolvent in I929, named a corporate fiduciary beneficiary of his endowment life insurance policies and deposited them with the beneficiary under a written agreement to the effect that the beneficiary should hold the proceeds of the policies, which were payable on the death of the insured, in trust for certain persons. Under the agreement, a right to withdraw the policies, to obtain the cash surrender value, to borrow and to

${ }^{\infty}$ Sacred Heart Church v. Fidelity Trust Co., supra note 63 , at 663 .

œ PA. Stat. AnN. (Purdon, I930) tit. I0, \$12. This Act provided in part as follows: "No estate, real or personal, shall hereafter be bequeathed, devised, or conveyed to any body politic, or to any person in trust, for religious or charitable uses, except the same be done by deed or will attested by two credible, and, at the time, disinterested witnesses, at least one calendar month before the decease of the testator or alienor, ... and all dispositions of property contrary hereto shall be void, and go (to) the residuary legatee or devisee next of kin, or heirs, according to law : Provided, That any disposition of property within said period, bona fide made for a fair valuable consideration, shall not be hereby avoided." 
receive values maturing prior to the death of the insured, and a power to revoke the agreement were reserved by the insured. It also appeared that the insured had a right to change the beneficiary. While nothing is said about payment of premiums in the opinion, it seems fairly clear that the agreement was unfunded. ${ }^{67}$. Later the insured withdrew two policies from the possession of the trustee and in November, I930, assigned them to Bose, as security for a loan, without a change of beneficiary. ${ }^{88}$ On the insured's death in I93I, the proceeds of the two policies were paid to Bose, who, after deducting his debt, paid the balance of the proceeds into court under a bill of interpleader. The trustee and administratrix were the interpleading parties. Other creditors of the insured were permitted to intervene.

The administratrix and the creditors attacked the validity of the trust on the ground that, due to the various rights reserved, the gift in trust was incomplete, that the trust, therefore, was testamentary in nature within the meaning of the Statute of Wills and that since the agreement was not executed with the formalities required by that statute, the entire agreement and the trust which it purported to create were void. The court held that the trustee was entitled to the proceeds as beneficiary of record, subject to a limited extent to claims of creditors, ${ }^{69}$ and further that such proceeds should be held by the trustee subject to the terms of the trust agreement. With respect to the argument advanced on the testamentary question, the court said :

"Whatever merit there may be to the points, were the res in trust the property of the truster, they are beside the question where, as here, the res is the proceeds of insurance on the life of the truster which

or The case has been considered as involving an unfunded transaction. See a PrentrceHalt Trust SERVICE (I933) \7718, at 7721.

${ }^{\infty}$ The assignment form which the insured used contained a parenthetical provision that upon execution of the assignment by the insured, it should effect a change of beneficiary to the insured's executors, administrators or assigns and there was also a provision in the body of the document, that, when the policies were released by the assignee, it should automatically be payable to the last beneficiary of record in the file of the insurer at the time of the release. At the time of the assignment, the insured again changed the beneficiary, naming the trustee, which change was filed with the insurer.

The court observed in this connection that the assignment, despite the provision contained therein with regard to automatic change of beneficiary to the insured's estate, did not actually so operate as such change could be properly accomplished only by recording such change with the insurer in accordance with the terms of the original contract, citing Anderson v. Broad Street National Bank, 90 N. J. Eq. 78, 105 Atl. 599 (19I8). The conclusion that the assignment did not operate as a change of beneficiary appears to be sound.

The court further observes that, if the assignment had operated as a change of beneficiary to the insured's estate, it was immediately defeated by the contemporaneous change of beneficiary made by the insured. This conclusion may be questioned. It would seem that upon assignment of the policies of the insured, if his estate was thereby made the beneficiary, all rights thereunder passed to the assignee and the insured no longer had a right to change the beneficiary on the policies. There would then be a question as to the effect of the provision in the assignment that upon release of the assignment the funds should be automatically payable to the last beneficiary of record.

$\varpi$ The court observed further that, since the assignment of the policies by the insured did not affect the beneficiary's rights under the policies, the right of Bose to deduct the debt was questionable, but that this point was not in issue in this case. 
never were his property. The proceeds are the fulfillment of promises by the insurance company to the . . . trustee, to pay the stipulated sums, upon the death of the insured. The insured paid the consideration for the promises and he had the right, under the terms of the policies, to change the promises at will, but when the day came-the insured's death-the obligations of the insurance company were due to the . . . trustee. Its source of title was the promise in the policies, not the trust agreement. The trust agreement is no more than a declaration of trust by the trustee that it would hold the proceeds of the policies for the benefit of the insured's wife and children, and whether it had physical possession of the policies or whether there was a stripping of interest by the 'donor', or that the trust deed was testamentary, is wholly immaterial." 70

On principle the position of the court approaches the view which has been advanced herein as a sound one. It is unfortunate, therefore, that the court did not review the authorities on this subject generally, and in particular that it failed to refer to Fagan $v$. Bugbee ${ }^{i 1}$ and to other decisions of the New Jersey courts. ${ }^{72}$ However, it is submitted that a consideration of these cases should not have altered the result reached by the court.

Within two weeks after the foregoing decision was handed down, the Appellate Court of the First District of Illinois, in Gurnett v. The Mutual Life Ins. Co. of New $\mathrm{York}_{,}{ }^{73}$ upon an entirely independent consideration and upon different grounds, also supported the validity of a revocable unfunded transaction. In this case it appeared that on December 2, I930, Knowlton L. Ames entered into an agreement in writing under seal with an Illinois trust company as trustee. This agreement recited that Ames, the insured, desired to create a trust of the proceeds of the insurance policies on his life described in a schedule annexed to the agreement, and further stated that the insured "hereby deposits" said policies with the trustee. The insured agreed to designate the trustee, or its successor, as beneficiary under the policies and also to pay all premiums thereon. It was provided also that additional policies could be deposited under the same terms. The insured reserved the power to withdraw all policies so deposited, and to exercise all rights originally reserved to him under the policies, including the right to change the beneficiary at any time, to obtain loans thereon, to pledge the policies, to receive dividends, and to surrender any or all policies and to receive the cash surrender value thereof. The insured also reserved a power, during his life, to revoke or amend the agreement, in whole or in part, subject to payment of compensation to the trustee for services rendered. For its part the trust company agreed to hold the

${ }^{30}$ Bose v. Meury, supra note 64 , at 63 , I63 Atl. at 277 .

"Supra note 53 .

72 Sell v. Steller, supra note 15 ; Cessna v. Adams, supra note 37.

${ }^{73} 268$ Iil. App. 5 I8 (I932) ; 2 PRENTICE-Hall TRUST Service (I933) lif 7717-7720; see also Fraser, supra note 5 , at $7723-7729$. 
policies in safekeeping during the life of the insured and upon his death to collect the proceeds and to hold and administer them upon certain trusts as provided in the agreement, for which services the trustee was to receive a fee deductible from the trust assets. Many of the insurance policies listed in the schedule annexed to the agreement were at the time payable to the insured's executors, administrators or assigns, but upon execution of the agreement the insured obtained a change of beneficiary designating the trustee as beneficiary. The policies were deposited with the trustee.

The original trust agreement was amended April 2, I93I, and June 25, I93I, by instruments under seal changing certain provisions as to powers of the trust company and certain items in the direction for disposition. The supplemental agreement dated April 2, I93I, provided that "the subject matter of the trust hereunder shall in the Assured's lifetime, and anything in this agreement to the contrary notwithstanding, consist of said policies made subject hereto, whether presently or in the future." 74

The insured died December 23, I931, leaving a will and naming his son and a trust company, successor to the trust company with which the above agreement was made, executor. The estate amounted to $\$ 50,000$, and creditors had claims in excess of $\$ 800,000$. At the time of the insured's death the face value of the insurance policies deposited with the trust company totalled over $\$ 1,000,000$. The contract creditors of the insured brought a bill in equity in behalf of themselves and other interested parties seeking to have the agreement and supplemental agreement declared void and the trust company declared to hold the proceeds of the policies upon a resulting trust in favor of the estate and that it be directed to pay the same to the executors. The complainants supported their position not upon the ground that there had been a transfer in fraud of creditors, as the bill contained no such allegation, but upon the ground that there had been no assignment of the policies, that because of the power to change the beneficiary of the policies reserved to the insured the trustee had a mere expectancy, that there was, therefore, no trust during the insured's life and hence the agreements were testamentary and did not conform to legal requirements for a testamentary disposition of property. The defendants moved to dismiss the bill on the ground that the facts alleged amounted in law to an assignment of policies and that even though there had been no assignment, there was a valid trust of the interest which the beneficiary received and that a reservation of a power to revoke did not alter this fact.

The lower court found that a valid trust had been created and dismissed the bill. On appeal the decree was affirmed. In concluding the discussion on the nature of the interest passing to the trustee under the agreement, the court made the following observations : 
"What was the nature of the right granted to the trustee? What did the trustee take? First, it took possession of the policies. It became a bailee. It had a right to reasonable compensation. It was a bailee for hire with all the legal rights and liabilities which arise out of that relationship. As against a wrongful taker it could have maintained an action of replevin, or as against one who converted the policies it could have maintained an action in trover. Secondly, it took the right to receive the proceeds of the policies. This right, it is true, might be revoked, but even the right of revocation was not absolute. There was a condition precedent named in the writings, namely, that the compensation of the trustee should first be paid. We think, too, that a necessary condition precedent must have been compliance with the rules of law in that regard under the provisions of the statute, if any, of the states in which the insurance policies were issued. What those were is not averred in the amended and supplemental bill.

"The right of Ames to revoke was not absolute. The trustee was not a mere beneficiary. It did not in this case take a mere expectancy as in the cases cited by complainants. The trustee was a beneficiary named pursuant to the terms of a contract under seal and executed for a valuable consideration, and the contract was in part executed by the trustee, it having entered upon the fulfillment of its promises under the terms of the contract.

"The legal title to these policies was somewhere. Where was it? Manifestly, it was either in Knowlton L. Ames or in the trustee. Ames by a writing under seal had divested himself of the title. He had substituted for himself his trustee. It is true that his action was revocable. He could on the performance of conditions precedent take back the right of possession and the right to receive the proceeds. $\mathrm{He}$ could upon compliance with conditions precedent take back and place anywhere he pleased the legal right to receive the proceeds of the policies upon maturity. Until he exercised that power the trustee held, as it seems to us, the legal title to these policies in trust for the parties named in the trust agreement. In other words, the result of the contract between the Insurance company and the assured and the contract between the assured and the trustee was to constitute the trustee a donet beneficiary under the law. See Restatement of the Law of Contracts, vol. I, sec. I33, p. I5 I." 75

It is submitted that the learned court acted properly in holding that the agreement and the trust created thereby were valid. However, the reasoning set forth in the above quotation, upon which the court reached the result, must be considered. It will be noted that in the last paragraph of the quotation the court concludes that "by a writing under seal" legal title to the policies was vested in the trustee subject to divestment. In view of the provision contained in the first supplemental agreement to the effect that the subject matter of the trust during the life of the insured should consist of the policies made subject to the agreement, it would seem that

${ }^{\pi}$ Gurnett v. The Mutual Life Ins. Co. of New York, supra note 73, at 530-53I. 
there might be some justification for reaching such a conclusion. If this conclusion is reached, however, it would seem that a trust was immediately created upon execution of the supplemental agreement. The validity of the trust could then be sustained upon the same grounds as an ordinary revocable trust inter vivos and consideration of the nature of the original agreement would appear to be unnecessary except as a supplemental argument.

The above reasoning was advanced by the defendants as a primary argument; confusion arises in reading the opinion because this argument appears at the very end, immediately following a long discussion which seems to be based upon the assumption that legal title to the policies did not pass to the trustee. So far as the assumption that no legal title to the policies passed to the trustee is concerned, it would seem that it might be entirely justified. Considering all three agreements as one for purposes of construction, it is entirely reasonable to argue that the wording in the first supplemental agreement was merely unfortunate and did not conform with the general plan, which considered as a whole indicates that the insured had no intention of assigning the policies, and that the legal title did not pass to the trustee. Looking at the agreements in this light, the court concluded that a valid bilateral contract had been created.

However, it will be noted that the court then holds that the trustee was not a mere beneficiary and that it took more than an expectancy, apparently upon the ground that the right to revoke was not absolute because of the provision as to compensation and further that the contract was under seal and executed for a valuable consideration. The defendants had urged as a secondary argument that the trustee held an interest which could be the subject of a valid trust even though there was no assignment. The court, therefore, seems to adopt this second argument by finding that the trustee acquired a vested interest apart from the title to the policies. This vested interest, however, appears not to be of the usual character since the court appeared to accept the weight of authority to the effect that the beneficiary of an insurance policy has merely an expectancy. It would seem that the confusion in the opinion arises from the fact that the court did not clearly indicate when it passed from a consideration of one line of reasoning, involving title to the policies, to the other line of reasoning directed solely to the interest which the trustee-beneficiary received. It seems that the court could have accepted the contention of the complainants that prior to the insured's death the trustee had a mere expectancy and still might have held the contract and the trust arising therefrom valid in all respects, upon the reasoning which has been outlined previously in this discussion. ${ }^{76}$

Federal Trust Co. v. Damron ${ }^{77}$ is another interesting case. Here it appeared that Corl E. Reynolds took out an insurance policy of $\$ 50,000$

"T See supra p. 712 et seq.

"Supra note 3 . 
on his life under which the usual rights were reserved, including the right to change the beneficiary on the policy. The policy was made payable to the Federal Trust Company as trustee. Reynolds was president of the trust company. As soon as the policy had been issued Reynolds entered into an agreement with the Federal Trust Company as trustee providing for disposition of the proceeds. Reynolds reserved a power to revoke the agreement but it does not appear in the report whether or not he specifically reserved a power to exercise the various rights reserved to him under the policy; he did agree to pay all premiums on the policy "during continuance of the trust". This agreement was revoked and on April 22, I927, a new agreement similar to the first agreement was executed. This second agreement was in turn revoked and another agreement executed August 2I, I930. This last agreement, which was the one before the court, is not described in detail but presumably it closely resembled the previous agreements in its routine provisions although it is not specifically so stated in the opinion.

With regard to the disposition of the proceeds, the agreement provided that the trustee should repay the Federal Trust Company with interest sums which it had advanced to pay premiums; to pay certain debts of the insured; to lend the balance to the Federal Trust Company for two years without interest on certain conditions; and at the end of the two year period, pay certain amounts to individuals, any balance remaining to the Federal Trust Company outright. This last agreement was signed by Reynolds in his own behalf and by Reynolds as President of the Federal Trust Company. Two witnesses also signed the document. The insured paid the first five monthly premiums on the policies but was reimbursed by the trustee for such payments and the trustee thereafter paid the premiums; but book entries were made indicating that these payments were in the nature of a loan to Reynolds. The insured died December 27, I930, and the trustee collected the proceeds. Thereafter, at a special stockholders' meeting at which the insured's executor voted the majority of the stock, the agreement was ratified. The Federal Trust Company filed a petition to determine its rights and duties with respect to the proceeds of the policy. The minority stockholders attacked the validity of the agreement on several grounds, one of which was that the agreement was void due to uncertainty and lack of mutuality and claimed that the Federal Trust Company was entitled to the proceeds free of the trust. The agreement was not attacked on the ground that it was a testamentary disposition. The lower court held the ratification of the agreement void and directed the trustee to pay over the proceeds to the Federal Trust Company free of trust. On appeal this holding was reversed, on the ground that an enforceable trust had been created, the court saying at the end of the opinion:

"It follows that the so-called trust agreement of August 21, I930, considered as a unilateral instrument executed by Corl $\mathrm{E}$. Reynolds 
alone as trustor, as a declaration of trust in connection with the payment and receipt of the insurance by the trust company, affords ample evidence to establish the creation of the trust, to identify the beneficiaries and defines and enumerates the duties and obligations which its terms require to be performed." 78

In other words the court appears to be of the opinion that even though the agreement is not considered as a valid bilateral contract because of the various powers reserved, nevertheless it may be considered as evidencing a unilateral transaction from which a valid trust may arise.

In view of the Statute of Wills in Nebraska, which requires two witnesses, ${ }^{79}$ it might be argued that in this case the requirements had been met, and the failure of counsel to raise the testamentary question and the failure of the court to discuss it might be explained on this ground. On the other hand, it is stated in the opinion that the agreement was signed by Reynolds in his own behalf and by Reynolds as President of the Federal Trust Company "in the presence of two witnesses who executed the document as such on the part of the trust company". It would seem possible to argue from this that the signature of Reynolds as an individual was not witnessed and that the requirements of the statute were not met. On this basis, the case might stand as authority sustaining the validity of unilateral transactions although the instrument evidencing the same is not executed in the manner required by the Statute of Wills.

The bilateral and unilateral transactions between the insured and the beneficiary so far discussed in this subdivision constitute the great majority of the so-called revocable unfunded insurance trusts, but there is one additional type which it might be well to consider since it appears to be even more tenuous than the foregoing arrangements. It is possible for the insured to name a trustee as beneficiary of a policy under a revocable designation and at the same time to make a revocable declaration of trust as to the proceeds. The insured during his life may notify the trustee or the trust beneficiary of the declaration and designation but this is not essential. Under the minority view, which holds that the revocably designated insurance beneficiary takes a vested interest subject to divestment, there would be an immediate trust, but following the opposite view supported by the weight of authority, such a declaration in effect appears to be an offer to the insurance beneficiary which may be withdrawn but which, if not so withdrawn prior to the death of the insured, may be accepted by the beneficiary at that time. The acceptance of the beneficiary at the time of death would complete the unilateral contract and an express trust would be created at that time.

${ }^{78} I d$. at 667,247 N. W. at 593.

To Neb. CoMrp. Stat. (I929) §30-205. 
A trust which arose from an arrangement of this type has been held valid although the form of the declaration did not satisfy the requirements of the Statute of Wills. Thus, in Lauterbach $v$. The New York Investment Co., ${ }^{80}$ it appeared that the insured held policies totaling $\$ 75,000$ which were payable to his wife, that he paid the premiums and that, pursuant to the right reserved in the policies, he changed the designation to "Alfred Lauterbach, Trustee". Shortly thereafter, the insured called at Lauterbach's office and, on being advised that Lauterbach was gone for the day, he handed to Lauterbach's clerk a sealed envelope and asked her to deliver the envelope to Lauterbach the following morning. At $4 \mathrm{~A}$. M. the following morning the insured committed suicide, and at ro A. M. the same morning, the said clerk delivered the envelope to Lauterbach. On opening the envelope, Lauterbach found the above mentioned insurance policies together with written instructions signed by the insured for the disposition of the proceeds "in case anything should happen to me". Lauterbach collected the proceeds and brought this suit for instructions for disposition of the funds. The court handed down a decree directing Lauterbach to dispose of the proceeds in accordance with the insured's written directions on the ground that a valid trust had arisen. This conclusion was reached although the court was of the opinion that the settlement was revocable, and despite the fact that the beneficiaries of the trust were certain creditors of the insured, who through enforcement of the trust were placed in a preferred position with respect to other creditors. The court said:

"The subject of the asserted trust was peculiarly one which became effective only upon the death of the creator of the trust, and hence the reference in the letter to Lauterbach as to the disposition to be made by him of the proceeds of insurance in case anything should happen to me' should not be treated as an attempted testamentary disposition of property, but as a declaration of the purposes of the trust created in the policies of insurance. The mere circumstance that the trust was subject to revocation on the part of the settlor during his lifetime is not inconsistent with a lawful trust which would continue effective as long as it remained unrevoked." 81

It will be noted that the court refers to "the trust created in the policies of insurance", but there is no discussion which would indicate that the court believed there had been an assignment of the policies. Further, there is little discussion with respect to the nature of the interest received by Lauterbach when named as beneficiary, but the court indicates that the wife had no vested rights in the policies from the circumstance that "she had been named as beneficiary". ${ }^{82}$ It would seem that if unfunded arrangements are

${ }^{\infty} 62$ Misc. 561, II7 N. Y. Supp. I52 (rgog).

${ }^{81}$ Id. at 565 , II7 N. Y. Supp. at 155 .

${ }^{2} C f$. Grems v. Traver, 87 Misc. 644, I48 N. Y. Supp. 200 (19I4), aff'd, I64 App. Div. 968, I49 N. Y. Supp. 1085 (I9I4); Wagner v. Thieriot, 203 App. Div. 757, I97 N. Y. Supp. 
to be considered testamentary dispositions, the court in this case would have held the declaration invalid but the trust was sustained. ${ }^{83}$

\section{(V) General Consideration of Unfunded Settlements and Contracts in Relation to Public Policy}

In the course of the present discussion the testamentary problems presented by life insurance trusts which are immediately created and those which are not immediately created but subsequently arise from a bilateral or unilateral transaction have been considered, various arguments have been set forth, and the authorities have been reviewed. ${ }^{s 4}$ Little consideration has been given to the general question of whether the various settlements and contracts should be sustained as a matter of policy.

Public policy favors the transfer of property by a person on his death to those whom he may designate provided the danger of fraud is reduced to a minimum. The Statute of Wills is an expression of this policy, the formalities required being a safeguard against fraud. There is also a strong public policy supporting the validity of ordinary life insurance policies unconnected with trust settlements, although such policies may not be executed with testamentary formalities on the grounds, first, that no transfer of property belonging to the insured is involved, and second, that even if in a sense an economic benefit may be considered as passing from the insured at the time of his death to the beneficiary, there is small chance for fraud

560 (I922), aff'd, 236 N. Y. 588, I42 N. E. 295 (I923), not involving trust settlements, where a wife who had been revocably designated as beneficiary under policies taken out by her husband on his life was held to take a vested interest on the theory that the husband took out the policies as "agent" of the wife. This strained construction apparently was adopted by the courts in order to exempt the benefits from claims of creditors under the provisions of New York Domestic Relations Law, section 52. The New York courts may not feel constrained to follow the theory adopted in the above cases, particularly where, as in Lauterbach v. The New York Investment Co., supra note 80, policies were payable when they eventually matured to a person other than the wife of the insured. Such a result would be in accordance with the weight of authority. This opinion is strengthened by the fact that due to the adoption of section 55-a, of the New York Insurance Law (Supp. I933), section 52 of the Domestic Relations Law has been largely superseded.

${ }^{\approx} C f$. Donithen v. Independent Order of Foresters, sutpra note I5.

$\$$ Personal funded life insurance trusts present similar problems which, insofar as insurance policies and their proceeds are concerned, do not differ from those discussed above. The funded transaction is colored by the fact that the settlor transfers securities to the trustee, the income from which is to be used directly or, in jurisdictions having laws against accumulations, indirectly in payment of premiums. The transfer of property other than insurance policies to the trustee strengthens the view that the settlor intends to make a present gift.

There are a few cases involving funded insurance trusts and none of them appear to involve directly the question whether these trusts are testamentary dispositions within the meaning of the Statute of Wills. See Matter of Haedrich (transfer tax); Burnet v. Wells (income tax), both supra note 6; Dupont v. Commissioner, 289 U. S. 685, 53 Sup. Ct. 766 (1933) (income tax). Cf. In re Marshall's Estate, I79 Minn. 233, 228 N. W. 920 (1930); Sacred Heart Church v. Fidelity Trust Company, supra note 63.

There are certain cases where the settlor did not transfer securities to the trustee but the trustee for consideration, agreed to pay premiums. See Wrather v. Stacy, supra note 35; Jackson v. Hughes, supra note 12. Cf. Scott v. Miller, supra note 38. See further Sell v. Steller; Brett v. Warnick, both supra note 15 ; Kerr v. Crane, supra note 35 , where the promise to pay premiums was made by the trust beneficiary. 
due to the interest of the insurer. The underlying reason for requiring testamentary formalities, therefore, is not present. In cases where insurance policies are coupled with trust settlements, it would seem that this element tending toward the prevention of fraud is strengthened, since the trustee is an additional party who will act in conjunction with the insurer to prevent fraudulent transactions.

But in addition to the foregoing consideration, a further element arising out of the peculiar nature of insurance is involved. Frequently, where a person carries insurance on his own life payable to dependents, such person will die leaving practically no assets other than his life insurance policies which, if payable to third parties, cannot be considered as an asset of his estate after death. In such cases, without the insurance proceeds, there is a possibility that the insured's dependents may become destitute, involving the danger that they may become public charges; with such insurance, however, these dependents may be cared for, with a corresponding relief from the danger that they may become objects of public charity. The public policy supporting the validity of ordinary life insurance contracts is based to no small extent upon this element of relief. ${ }^{85}$ But in many cases where a substantial amount of insurance is involved, if proceeds are paid directly to the insured's dependents, due to lack of experience or improvidence, there is grave danger that the proceeds may be dissipated unwisely. Insurance trust settlements are designed to prevent such dissipation.

To the extent to which unwise dissipation of insurance proceeds is prevented, there is a permanent economic benefit to the individual and to the state both directly and indirectly. At the beginning of this article, it was observed that today life insurance policies having an aggregate face value of over four billion dollars are either held in trust or have their proceeds payable to trustees under life insurance trust settlements of various types. ${ }^{86}$ The normal expectancy is that this aggregate amount will steadily increase. When it is considered that such an amount is to be held in trust under conservative management for a number of years, with the result that the principal involved will become available for sound corporate and governmental financing through investment by the trustee, and that the income therefrom will give the beneficiaries a financially independent status as a result of which they will become steady consumers of goods without danger of becoming public charges, the value of this benefit to the individual and to society cannot be lightly dismissed. It would seem, therefore, that not only are these unfunded settlements and contracts directly in harmony with the general public policy which dictates support of ordinary life insurance con-

$\approx$ The strength of public policy supporting the ordinary life insurance contract is illustrated by those exemption statutes which protect to a varying extent the cash surrender values and proceeds of insurance policies from claims of creditors of the insured.

${ }^{86}$ See Note (1933) 46 Harv. L. Rev. $818 \mathrm{n}$. I. 
tracts where no settlement is involved, but that they are supported by further considerations of policy not otherwise present.

\section{Conclusion}

In the course of this article, the writer has attempted to set forth the various arguments bearing upon the testamentary problem as it relates to personal unfunded life insurance trust arrangements of various types. The primary argument that the proceeds of an insurance policy are never part of the insured's estate when payable to third parties, and that as a result there can be no disposition of the proceeds which can be considered testamentary within the meaning of the Statute of Wills, was discussed and supplemented by an analysis of the more common unfunded settlements and contracts, a review of the authorities and a discussion of public policy. While subsequent developments in the use of this general method of disposing of insurance proceeds and later decisions may require a reexamination of all or a part of this subject, at present it would seem apparent, first, that the primary argument has not been discredited, since the supplemental arguments in support of such settlements and contracts are as logical, if not more so, than the arguments which attack their validity; second, that the authorities, although they present varied lines of reasoning, with few exceptions are favorable, in many cases directly sustaining the validity of such arrangements; and lastly, that these arrangements are not contrary to public policy but are in fact favored by it. 